\title{
EFFECT MICRO IRRIGATION SYSTEMS, IRRIGATION PERIOD AND SEED THICKNESS ON BARLEY SPROUT PRODUCTION
}

\author{
Gomaa Abd-Rbo Bakeer ${ }^{1}$ Khaled . K. Hegab $^{2}$ Usama .A. El- \\ Behairy ${ }^{3}$ Wessam. E. El-sawy 4
}

\section{ABSTRACT}

The experiments carried out during July 2014 in hydroponics unit in Qwisna, El-Minufia governorate. The objective of this experiment is to study the effect of different nozzles (fogger, mist and mini sprinklers), irrigation periods (30sec, 60sec and 90sec) for (2hr,4hr and 6hr) respectively and seed thickness in the trays $(0.5,1.0$ and $1.5 \mathrm{~cm})$ on barely sprouts produced hydroponically. Measurements were taken for every production unit (WUE, yield/tray, yield/kg seed, protein \%, fibers\%). Data showed that using fogger gave the highest CU\% , DU\%, water use efficiency, yield/kg seed, protein \%, fiber \% and carbohydrates \%. On the other hand, data illustrated that using $0.5 \mathrm{~cm}$ seed thickness recorded the highest yield/kg seed, protein \%, fiber \% and carbohydrates \%. Concerning using $30 \mathrm{sec} / 2 \mathrm{hr}$ recorded the highest water use efficiency, yield/kg seed, protein \%, fiber \% and carbohydrates \%.

Finally, from the overall results it can concluded that using $0.5 \mathrm{~cm}$ seed thickness irrigated $30 \mathrm{sec} / 2 \mathrm{hr}$ with fogger recorded the highest tested parameters.

\section{INTRODUCTION}

$\mathrm{W}$ ater and agriculture are interdependent and critical to the wellbeing, economy, and security of our society. The safety, security, sustainability, and policy issues associated with water and agriculture are vital to Egyptian interests. Irrigated agriculture is the major user of water in most parts of the world.

1- Prof. of Ag. Eng. Dept. Fac. of Ag. Cairo Univ.

2- Assoc. Prof. of Ag. Eng. Dept. Fac. of. Ag. Cairo Univ.

3- Prof of Horticulture Dept. Fac. of Ag. Ain-Shams Univ.

4- Post grad. Student of Ag. Eng. Dept. Fac. of. Ag. Cairo Univ . 
Stress on water availability and associated impacts among competing user groups in the region is increasing due to population growth, development, environmental \& wildlife concerns, the persistence of below-normal precipitation, and water compact requirements on river Nile. The science of using hydroponically grown forage to provide cattle and sheep with sustenance is not a new one, but its application in the Egypt has only recently begun. Where commercial operations and applications for forage has served as a viable option where water conservation is a central issue or where reliable forage quality desired. The process is started over again after cleaning the tray. With a greenhouse, there are 7 to 10 different crops growing at any one time and only a fraction of the greenhouse contents is harvested each day, including weekends . So, it is essentially a forage factory. The covered structure eliminates the evaporative loss that dominates the water consumption by open field forage crops (Al-Hashmi, 2008) .

The process for growing hydroponic forage goes as follows. The grain, which can be wheat, corn, barley, sorghum or oats cleaned with a dilute chlorine solution and then rinsed. (Rodriguez-Muela et al., 2004) The seeds are then placed in a tub with water for 12 hours and soaked to loosen the seed coat. The seeds are then drained and placed on trays for growing. The trays are kept wet with a sprinkler system and in 7-10 days are 10 inches tall and fed to the livestock, roots and all. (Dung et al. 2010).

Hydroponic forage is comparable in most of the categories and above in a few. The only category in which hydroponic forage is at a disadvantage is that of dry matter percent. But this is an advantage in that cattle then require less water when they're being fed the green grass. (Howard, 1989) In essence, we are getting the most crops per drop and also getting a second use out of the irrigated water by reducing the water intake by the livestock ( Schroder and Leith 2002) .

Water use efficiency under hydroponic system :

About 1.5-2 liters are needed to produce $1 \mathrm{~kg}$ of green fodder hydroponically in comparison to 73, 85, and 160 liters to produce $1 \mathrm{~kg}$ of green fodder of barley, alfalfa, and Rhodes grass under field conditions, respectively. Water is one of the basic requirements for seed germination 
and seedling growth as it is essential for enzyme activation, reserve storage breakdown, translocation, and use in seed germination and seedling growth (Al-karaki, 2010) . Hydroponically produced fodder was found to enhance the efficiency of water use (WUE). Hydroponic green fodder production technique requires only about $10-20 \%$ of the water needed to produce the same amount of crop in soil culture (Bradley and Marulanda, 2000). While only 3-5\% of water is needed to produce the same amount of fodder in comparison to that produced under field conditions. Water use efficiency (WUE) of only 14 and $12 \mathrm{Kg}$ forage fresh matter $/ \mathrm{m}^{3}$ water for field irrigated barley and alfalfa, respectively, compared to that of 645 and $521 \mathrm{~kg}$ fresh matter/m3 water in barley and alfalfa obtained in hydroponic system, respectively reported by (AlKaraki and Al-Momani 2011) .

\section{Overall, the main advantages of hydroponics over soil culture are:}

More efficient nutrition regulation, availability in regions of the world having non arable land, efficient use of water and fertilizers units, no water stress on plants, ease and low cost of sterilization of the media, no need weed controlling ability medium temperature can be maintained optimum by flooding with the nutrient solution and higher density planting, leading to increased yields per unit area (El-Deeba 2009). The aim of this paper investigate the effect of micro irrigation system , irrigation period and seed thickness in the tray on barley sprout produced hydroponically.

\section{MATERIALS AND METHODS}

The experiments carried out during July 2014 in private hydroponics unit in Qwisna city, El-Minufia governorate, Egypt .

\section{1-Experimental layout :}

Experimental layout had been described in Fig (1), the experimental layouts included:

\section{Hydroponic room}

Hydroponic unit $\left(4^{*} 6\right) \mathrm{m}^{2}$ constructed from cconcrete and its components are [ lighting system, aeration and cooling system, irrigation and nutrients applying system and cultivation units (stands \& trays)] . The lighting system was used to provide forage with its light requirement. Digital 
Thermometer used for measuring temperature and humidity inside room to control it and maintain the growth chamber with appropriate temperature and humidity and avoid the problems caused by increasing temperature and humidity. The irrigation system was controlled by control panel.

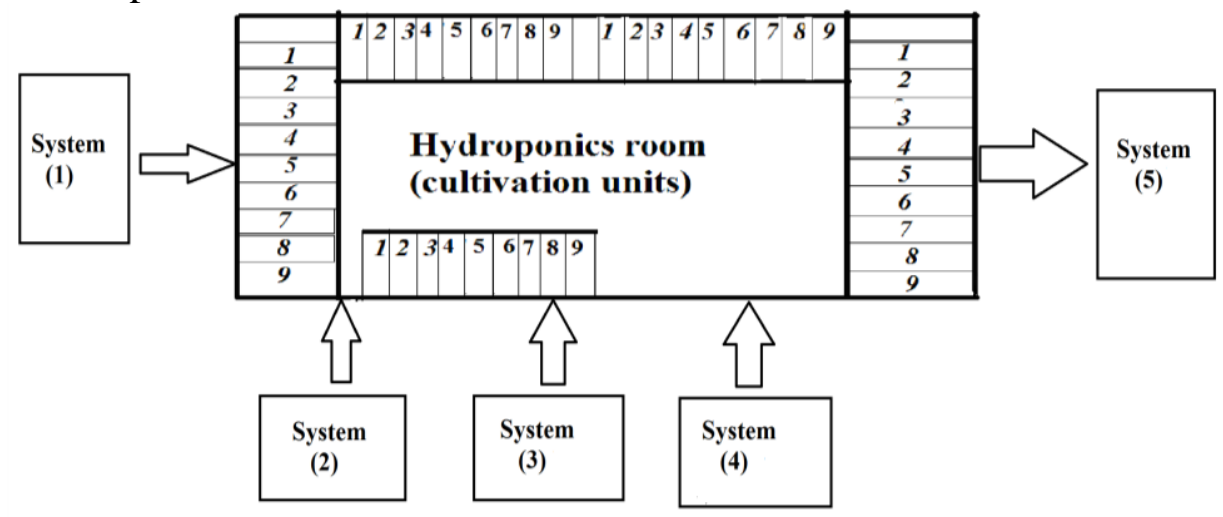

Fig (1): Experimental layout

Fig (1) shows the experiment layout included :

System (1) Seed preparation and batching,

System (2) Lighting, aeration, humidity and temperature control,

System (3) Applying and and nutrient solution,

System (4) Irrigation and nutrient and

System (5) Green fodder harvesting system.

\section{$\underline{\text { Irrigation system }}$}

Irrigation system consists of:

1.Three HP pump to convey the water from storage tank to supplementary irrigation system.

2.Water storage tank with 500 liter size for storing the water and nutrients solution.

3.Tubes (P.E) $32 \mathrm{~mm}$ outside diameter connected pump to the irrigation system

4.Tubes (P.E) $16 \mathrm{~mm}$ outside diameter was connected tubes $32 \mathrm{~mm}$ to mini sprinkler.

5.PVC valves to control the amount of water fed to every stand.

6.Electronic controller circuit to control the timing and duration of opening and closing of the valve.

7-Different type of nozzles : 
Three different types of nozzles used in the experiment shows as in Table (1):

Table (1): Sprayer systems specifications :

\begin{tabular}{|c|c|c|c|c|}
\hline Nozzle type & $\begin{array}{c}\text { Head } \\
(\mathbf{m})\end{array}$ & $\begin{array}{c}\text { Discharge } \\
(\mathbf{L p h})\end{array}$ & $\begin{array}{c}\text { Coverage } \\
\text { diameter } \\
(\mathbf{c m})\end{array}$ & $\begin{array}{c}\text { Droplets } \\
\text { volume } \\
(\mathbf{m i c r o n})\end{array}$ \\
\hline Fogger & 35 & 40 & 70 & 70 \\
\hline Mist sprayer & 30 & 61 & 110 & 100 \\
\hline $\begin{array}{c}\text { Mini } \\
\text { sprinkler }\end{array}$ & 20 & 130 & 150 & 200 \\
\hline
\end{tabular}

Technical properties of micro irrigation systems :

*The application uniformity (CU) .

* Distribution uniformity (DU) .

*Water use efficiency (WUE) .

\section{Hydraulic performance of different nozzles :}

The intensity was determined by measuring the volume of water accumulated during known interval, in closely placed containers. However, the collected water in the catch cans during the selected operating time were measured by means of a graduate glass cylinder.

The intensity of sprinkler is usually expressed as the depth of water falling in unit time, and calculated by the following equation:

$$
I=\frac{Q}{A \times T} \times 600 \quad \rightarrow E q(1)
$$

Where:

$I \quad$ : Sprinkler intensity, $(\mathrm{mm} / \mathrm{h})$

$Q$ : Water volume, $\left(\mathrm{cm}^{3}\right)$.

A : Area of unit, $\left(\mathrm{cm}^{2}\right)$.

$\mathrm{T}$ : Operating time, (min.)

\section{Experimental procedure and treatments:}

Technical parameters and associated treatments had been considered to evaluate the grass-fodder production under hydroponic system, as following: 


\section{Engineering factors:}

\section{1- Irrigation systems :}

Three different nozzles of irrigation systems were used in the experiment, systems (fogger, mist sprayer and mini sprinkler) have different (discharges, operating pressures, wet diameters and droplets volume).

\section{2- Irrigation period :}

Three irrigation period were used in the experiment $30,60,90 \mathrm{sec}$ for 2,4,6 hour respectively .

\section{Agro-biotechnology}

\section{1- Seed layer thickness}

Different Seed layer thickness $0.5 \mathrm{~cm}=692 \mathrm{gm}, 1 \mathrm{~cm}=1253 \mathrm{gm}, 1.5 \mathrm{~cm}$ $=1620 \mathrm{gm}$ in growth unit (tray) $(30 * 70 * 5) \mathrm{cm}^{3}$.

\section{2- Nutrient solution concentration}

Solution applied was N.P.K (20: 20: 20) with concentration 1cm/litre EC and $\mathrm{pH}$ of the nutrient solution had been adapted by $\mathrm{pH}$ and $\mathrm{EC}$ meter.

\section{Growing considerations:}

- Barley seeds (Giza, 121), was used in this study.

- Barely was sterilized before transplant in tray by using sodium hypochlorite in water.

\section{Quality indictors:}

At the end of experiment ( 6 days after seeding), the produced green fodder was ready for harvest, and green plants with their roots in the trays were harvested and the following data were recorded

\section{Performance evaluation of s:}

\section{1- Uniformity coefficient (CU\%) :}

For specifying the best shape of water distribution over the trays, the application uniformity was determined to see how evenly the water distribution for different discharges, operating pressure, cans were distributed in growth units (trays) to evaluate nozzles performance during operating. The application uniformity is estimated using Christiansen uniformity coefficient (CU) and distribution uniformity (DU). The Christiansen uniformity coefficient is a parameter that is widely used to evaluate application uniformity (Mosh, 2006; Sandra, et al, 2001). 


$$
C U=100\left(1.0-\frac{\sum_{i=1}^{n}|z-m|}{\sum_{i=1}^{n} z}\right) \quad \rightarrow E_{q}(2)
$$

\section{Where :}

$\mathrm{CU}=$ Christiansen uniformity coefficient \%,

$\mathrm{z}=$ Individual depth of catch observations from uniformity test $(\mathrm{mm})$,

$\mathrm{m}=$ Mean depth of observations $(\mathrm{mm})$ and

$\mathrm{n}=$ number of observations .

\section{2- Distribution uniformity (DU\%) :}

Determination of CU has an advantage of controlling all factors in the process, especially sprinkler water distribution. Thus allowing us to establish comparisons between different sprinklers (Montero et al. 1999) - The distribution uniformity is a ratio expressed in a percent of the average low-quarter amount caught to the average amount caught as express in equation (Keller and Blienser 1990).

$$
D U=\frac{\hat{X}_{L}}{\hat{X}} \times 100 \quad \rightarrow E q(3)
$$

Where :

$\hat{X}_{L}$ : The average low-quarter amount caught or infiltrated (mm),

$\hat{X}$ : The average amount caught or infiltrated (mm) .

\section{3 - Water use efficiency (WUE):}

Water use efficiency is The total added and drained water out of trays were recorded to compute for total water use (liters water used/ $\mathrm{kg}$ fresh fodder produced) and water use efficiency ( $\mathrm{kg}$ fresh fodder produced/liter water used) Al-karari and Al-Momani (2011), it is an indicator of efficiency of irrigation unit for increasing crop yield. Water use efficiency of yield was calculated according to (Al-karari ana AlHashimi, 2012).

$$
W U E(k g / L)=\frac{T_{p}(k g / \text { tray })}{T_{l}(L / \text { tray })} \times 100
$$




\section{Where :}

$T_{p}$ : Total green fodder produced ( $\mathrm{kg} /$ tray) .

$T_{l}:$ Total water used (liter/ tray) .

Technical properties of micro irrigation systems :

* The application uniformity (CU) .

* Distribution uniformity (DU) .

*Water use efficiency (WUE) .

\section{Yield quality parameters:}

* Sprout yield weight (g/tray),

* Sprout yield (g/kg seeds),

* Protein content \% ,

*Fiber content $\%$,

*Carbohydrates content $\%$.

* Samples were taken from every tray, weighed and put in the oven in $70^{\circ} \mathrm{C}$ for 48 hours to evaluate moisture content (\%), dry matter (\%), then protein $(\%)$, fibers $(\%)$ and carbohydrates $(\%)$.

\section{Experimental design and statistical analysis}

A factorial complete randomize block design with three factors ( sprinkler type, irrigation period and seed thickness in the tray) was used for analysis all data with three replications. The treatment means were compared by least significant difference (LSD) test as given by (Snedecor and Cochran (1994)). Statistical analysis was carried out by special statistical program (ASSISTAT) (Silva and Azevedo, 2009) .

\section{RESULTS AND DISCUSSION}

\section{Technical properties of nozzles :}

Table (2) : CU\% and DU\% of utilized nozzles were calculated in the experiment as follows :

\begin{tabular}{|c|c|c|c|c|c|}
\hline Sprayer system & $\begin{array}{c}\text { Head } \\
(\mathbf{m})\end{array}$ & $\begin{array}{c}\text { Discharge } \\
(\mathbf{L p h})\end{array}$ & $\begin{array}{c}\text { Coverage } \\
\text { diameter } \\
(\mathbf{c m})\end{array}$ & CU\% & $\begin{array}{c}\text { DU } \\
\%\end{array}$ \\
\hline Fogger & 35 & 40 & 70 & 95.6 & 90.82 \\
\hline Mist sprayer & 30 & 61 & 110 & 91.42 & 82.6 \\
\hline Mini sprinkler & 20 & 130 & 150 & 86.43 & 80.8 \\
\hline
\end{tabular}


CU and DU were determined to see how evenly the water distribution patterns under three types of microspriklers for different discharges, operating pressure and nozzle heights. The values of $\mathrm{CU}$ and DU for different discharges are illustrating in Tables (2) .

From the values of CU and DU for different types of microsprinkler, it can be arranged in descending order as follows; fogger microsprinkler type > mist sprayer type > mini sprinkler type .

The water droplet volume of fogger microsprinkler type is smaller than of those for mist sprayer type and mini sprinkler. The maximum CU and DU were adopted under 3.5 and 3 bar operating pressure for both types fogger sprinkler type and mist sprayer type under $70 \mathrm{~cm}$ and $110 \mathrm{~cm}$ coverage diameter for, respectively .

\section{Water use efficiency}

The effect of sprinkler type, period of irrigation and thickness of seeds in the tray on water use efficiency presented in Table (3). Regarding the type of sprinkler, data showed that sprinkler had a significant effect on WUE where the WUE were the highest using the mist sprayer comparing with the other sprinkler types.

On the other hand, data showed that irrigation period (30 sec/2hr) increased WUE significantly comparing with the other irrigation period.

Concerning the seed thickness, data showed that using $1 \mathrm{~cm}$ thickness of seeds recorded the highest WUE comparing with the other seed thickness. Data in table (3) show that the effect sprinkler type, period of irrigation and thickness of seeds in the tray on water use efficiency (WUE). Data showed that using mist sprayer increased water use efficiency (WUE) significantly compared with the other type of sprinkler.

Regarding the effect of irrigation period, data showed that $30 \mathrm{sec} / 2 \mathrm{~h}$ increased water use efficiency (WUE) significantly comparing with the other irrigation periods.

Data showed also that using $1 \mathrm{~cm}$ thickness of seeds in the tray increased water use efficiency (WUE) significantly comparing with other seed thickness. Regarding the interaction between sprinkler types and irrigation period, data showed that the highest WUE recorded by fogger combined with $(30 \mathrm{sec} / 2 \mathrm{hr})$. 
Table (3): WUE ( g / L) affected by sprinkler type, period of irrigation and thickness of seeds in the tray

\begin{tabular}{|c|c|c|c|c|c|}
\hline \multirow[b]{2}{*}{ Sprinkler } & \multirow{2}{*}{$\begin{array}{c}\text { Periods } \\
\text { (Sec) }\end{array}$} & \multicolumn{3}{|c|}{ Thickness of seeds $(\mathrm{cm})$} & \multirow[b]{2}{*}{ Mean } \\
\hline & & 0.5 & 1 & 1.5 & \\
\hline \multirow{6}{*}{$\begin{array}{l}\text { Fogger } \\
\text { Mean }\end{array}$} & $30 \mathrm{sec} / 2 \mathrm{hr}$ & 471.28 & 752.55 & 877.57 & 700.47 \\
\hline & $60 \mathrm{sec} / 4 \mathrm{hr}$ & 377.54 & 815.02 & 0 & 397.52 \\
\hline & $90 \mathrm{sec} / 6 \mathrm{hr}$ & 200.39 & 0 & 0 & 66.8 \\
\hline & & 349.74 & 522.52 & 292.52 & 388.26 \\
\hline & $30 \mathrm{sec} / 2 \mathrm{hr}$ & 384 & 547.99 & 711.92 & 547.97 \\
\hline & $60 \mathrm{sec} / 4 \mathrm{hr}$ & 302.07 & 467.01 & 467.01 & 412.03 \\
\hline \multirow{4}{*}{$\begin{array}{c}\text { Mist sprayer } \\
\text { Mean }\end{array}$} & $90 \mathrm{sec} / 6 \mathrm{hr}$ & 412.37 & 576.3 & 0 & 329.56 \\
\hline & & 366.15 & 530.43 & 392.98 & 429.85 \\
\hline & $30 \mathrm{sec} / 2 \mathrm{hr}$ & 289.5 & 366.4 & 0 & 218.63 \\
\hline & $60 \mathrm{sec} / 4 \mathrm{hr}$ & 232.29 & 328.44 & 289.98 & 283.57 \\
\hline Mini sprinkler & $90 \mathrm{sec} / 6 \mathrm{hr}$ & 270.7 & 213 & 0 & 161.23 \\
\hline Mean & & 264.16 & 302.61 & 96.66 & 221.15 \\
\hline Fogger & & 381.59 & 555.65 & 529.83 & 489.02 \\
\hline Mist sprayer & & 303.97 & 536.82 & 252.33 & 364.37 \\
\hline Mini sprinkler & & 294.49 & 263.1 & 0 & 185.86 \\
\hline Mean & & 326.68 & 451.86 & 260.72 & \\
\hline
\end{tabular}

LSD value at 0.05 :

Sprinkler (A) : 0.99

Thickness (C) : 0.99

$\mathbf{A} \times \mathbf{B}$

$\mathbf{B} \times \mathbf{C}$

On the other hand, data showed that using fogger combined with $1 \mathrm{~cm}$ seed thickness recorded the highest WUE followed by mist sprayer with $1 \mathrm{~cm}$ seed thickness while the lowest WUE recorded by mini sprinkler combined with $1.5 \mathrm{~cm}$ seed thickness

Concerning the interaction between irrigation period and seed thickness, data showed that highest WUE obtained using (30 sec/ 2hr) combined with $1 \mathrm{~cm}$ seed thickness while the lowest WUE recorded by mini sprinkler combined with $1.5 \mathrm{~cm}$ seed thickness.

Concerning the interaction among sprinkler type, irrigation period and thickness of seeds layer data in Table (3) showed that the highest WUE 
was obtained by using fogger with irrigation period (30 sec/ $2 \mathrm{hr})$ and seeds layer thickness was $(1.5 \mathrm{~cm})$ in the tray .

\section{Yield parameters}

\section{Sprout yield}

Data in Table (4) illustrated the effect sprinkler type, period of irrigation and thickness of seeds in the tray on sprout yield/ tray. Data showed that using mist sprayer increased sprout yield/tray significantly compared with the other type of sprinkler.

Table (4) Sprout yield ( $\mathrm{g} /$ tray) at harvest affected by sprinkler type, period of irrigation and thickness of seeds in the tray.

\begin{tabular}{|c|c|c|c|c|c|}
\hline \multirow[t]{2}{*}{ Sprinkler } & \multirow{2}{*}{$\begin{array}{l}\text { Periods } \\
(\mathrm{Sec})\end{array}$} & \multicolumn{3}{|c|}{ Thickness of seeds $(\mathrm{cm})$} & \multirow{2}{*}{ Mean } \\
\hline & & 0.5 & 1 & 1.5 & \\
\hline \multirow[t]{3}{*}{ Fogger } & $30 \mathrm{sec} / 2 \mathrm{hr}$ & 5000 & 8001 & 9334 & 7445 \\
\hline & $60 \mathrm{sec} / 4 \mathrm{hr}$ & 4000 & 8667 & 0 & 4222 \\
\hline & $90 \mathrm{sec} / 6 \mathrm{hr}$ & 3000 & 0 & 0 & 1000 \\
\hline \multirow{4}{*}{$\begin{array}{c}\text { Mean } \\
\text { Mist } \\
\text { sprayer }\end{array}$} & & 4000 & 5556 & 3111 & 4223 \\
\hline & $30 \mathrm{sec} / 2 \mathrm{hr}$ & 4667 & 6667 & 8667 & 6667 \\
\hline & $60 \mathrm{sec} / 4 \mathrm{hr}$ & 3667 & 5667 & 5667 & 5000 \\
\hline & $90 \mathrm{sec} / 6 \mathrm{hr}$ & 5001 & 7000 & 0 & 4000 \\
\hline & & 4445 & 6445 & 4778 & 5223 \\
\hline \multirow[t]{3}{*}{$\begin{array}{c}\text { Mini } \\
\text { sprinkler }\end{array}$} & $30 \mathrm{sec} / 2 \mathrm{hr}$ & 5001 & 6334 & 0 & 3778 \\
\hline & $60 \mathrm{sec} / 4 \mathrm{hr}$ & 4000 & 5667 & 5000 & 4889 \\
\hline & $90 \mathrm{sec} / 6 \mathrm{hr}$ & 4667 & 3667 & 0 & 2778 \\
\hline Mean & & 4556 & 5223 & 1667 & 3815 \\
\hline Fogger & & 4889 & 7001 & 6000 & 5963 \\
\hline $\begin{array}{l}\text { Mist } \\
\text { sprayer }\end{array}$ & & 3889 & 6667 & 3556 & 4704 \\
\hline $\begin{array}{l}\text { Mini } \\
\text { sprinkler }\end{array}$ & & 4223 & 3556 & 0 & 2593 \\
\hline Mean & & 4334 & 5741 & 3185 & \\
\hline
\end{tabular}

LSD value at 0.05 :

Sprinkler (A): 822

Periods (B) : 822

Thickness (C) : 822

Interactions: 2466
$\mathbf{A} \times \mathbf{B}$
$\mathrm{A} \times \mathbf{C}$
$\mathrm{B} \times \mathrm{C}$ 
Regarding the effect of irrigation period, data showed that $30 \mathrm{sec} / 2 \mathrm{~h}$ increased sprout yield/tray significantly comparing with the other irrigation periods. Data showed also that using $1 \mathrm{~cm}$ thickness of seeds in the tray increased sprout yield/tray significantly comparing with other seed thickness.

Concerning the effect of the interaction between sprinkler type and irrigation period on sprout yield/tray, data showed that the highest yield/tray recorded using fogger combined by (30 sec/2hr) followed by mist sprinkler with the same irrigation period while the lowest yield/tray obtained by mini sprinkler combined with ( $90 \mathrm{sec} / 6 \mathrm{hr}$ ).

Regarding the interaction between sprinkler type and seed thickness on sprout yield/tray, data should that using mist sprinkler combined with 1 $\mathrm{cm}$ thickness recorded the highest sprout yield/tray followed by using similar sprinkler with $1.5 \mathrm{~cm}$ thickness and mist sprinkler combined with $1 \mathrm{~cm}$ seed thickness. The lost yield/ tray obtained by mini sprinkler combined with $1.5 \mathrm{~cm}$ seed thickness.

On the other hand, data illustrated that using $1 \mathrm{~cm}$ thickness irrigated by $30 \mathrm{sec} / 2 \mathrm{~h}$ recorded the highest sprout yield/tray followed by $1.5 \mathrm{~cm}$ seed thickness irrigated by $30 \mathrm{sec} / 2 \mathrm{hr}$ while the lowest yield/ tray obtained by mini sprinkler irrigated by $90 \mathrm{sec} / 6 \mathrm{hr}$.

Regarding effect of the interaction among sprinkler type, irrigation period and thickness on sprout yield/tray, data showed that the highest yield was recorded using fogger combined with $1.5 \mathrm{~cm}$ seed thickness irrigated 30 sec/ $2 \mathrm{hr}$ followed by mini sprinkler combined with the same seed thickness irrigated $30 \mathrm{sec} / 2 \mathrm{hr}$. The lowest yield/tray recorded using all sprinkler combined with $1.5 \mathrm{~cm}$ irrigated $90 \mathrm{sec} / 6 \mathrm{hr}$.

\section{Sprout yield (g /kg seed):}

Data in Table (5) illustrated the effect sprinkler type, period of irrigation and thickness of seeds in the tray on sprout yield $(\mathrm{g} / \mathrm{kg}$ seed). Data showed that using mist sprayer increased sprout yield $(\mathrm{g} / \mathrm{kg}$ seed) significantly compared with the other type of sprinkler. Regarding the effect of irrigation period, data showed that $30 \mathrm{sec} / 2 \mathrm{~h}$ increased sprout yield ( $\mathrm{g} / \mathrm{kg}$ seed) significantly comparing with the other irrigation periods. Data showed also that using $0.5 \mathrm{~cm}$ thickness of seeds in the tray 
increased sprout yield ( $\mathrm{g} / \mathrm{kg}$ seed) significantly comparing with other seed thickness.

Table (5) Sprout yield ( $\mathrm{g} / \mathrm{kg}$ seed) at harvest affected by sprinkler type, period of irrigation and thickness of seeds in the tray.

\begin{tabular}{cccccc}
\hline \multirow{2}{*}{ Sprinkler } & $\begin{array}{c}\text { Periods } \\
(\mathrm{Sec})\end{array}$ & \multicolumn{3}{c}{ Thickness of seeds $(\mathrm{cm})$} & \multirow{2}{*}{ Mean } \\
\cline { 3 - 5 } & $30 \mathrm{sec} / 2 \mathrm{hr}$ & 7225 & 6384 & 5759 & 6456 \\
Fogger & $60 \mathrm{sec} / 4 \mathrm{hr}$ & 5780 & 6916 & 0 & 4232 \\
& $90 \mathrm{sec} / 6 \mathrm{hr}$ & 4335 & 0 & 0 & 1445 \\
Mean & & 5780 & 4433 & 1919 & 4044 \\
& $30 \mathrm{sec} / 2 \mathrm{hr}$ & 6743 & 5320 & 5347 & 5803 \\
Mist & $60 \mathrm{sec} / 4 \mathrm{hr}$ & 5298 & 4522 & 3496 & 4438 \\
sprayer & $90 \mathrm{sec} / 6 \mathrm{hr}$ & 7226 & 5586 & 0 & 4270 \\
Mean & & 6423 & 5143 & 2948 & 3837 \\
Mini & $30 \mathrm{sec} / 2 \mathrm{hr}$ & 7226 & 5054 & 0 & 4093 \\
sprinkler & $60 \mathrm{sec} / 4 \mathrm{hr}$ & 5780 & 4522 & 3085 & 4462 \\
Mean & $90 \mathrm{sec} / 6 \mathrm{hr}$ & 6743 & 2926 & 0 & 3223 \\
Fogger & & 6583 & 4167 & 1028 & 3926 \\
Mist & & 7064 & 5586 & 3702 & 5450 \\
sprayer & & 5619 & 5320 & 2194 & 4377 \\
Mini & & & & & \\
sprinkler & & 6102 & 2837 & 0 & 2979 \\
Mean & & 6262 & 4581 & 1965 & \\
\hline
\end{tabular}

LSD value at 0.05 :

Sprinkler (A): 783

Thickness (C) :783
Periods (B) : 783

Interactions: 2359
$\mathbf{A} \times \mathbf{B}$
$\mathbf{A} \times \mathbf{C}$
$\mathbf{B} \times \mathbf{C}$
$\mathbf{A} \times \mathbf{B} \times \mathbf{C}$

Concerning the effect of the interaction between sprinkler type and irrigation period on sprout yield $(\mathrm{g} / \mathrm{kg}$ seed), data showed that the highest yield $(\mathrm{g} / \mathrm{kg}$ seed) recorded using fogger combined by (30 sec/2hr) followed by mist sprinkler with the same irrigation period. The lowest yield $(\mathrm{g} / \mathrm{kg}$ seed) obtained by fogger sprinkler combined with (90 sec/6hr). 
Regarding the interaction between sprinkler type and seed thickness on sprout yield ( $\mathrm{g} / \mathrm{kg}$ seed), data should that using mini sprinkler combined with $0.5 \mathrm{~cm}$ seed thickness recorded the highest sprout yield $(\mathrm{g} / \mathrm{kg}$ seed) followed by using mist sprinkler with the same seed thickness. The lowest yield $(\mathrm{g} / \mathrm{kg}$ seed) obtained by mini sprinkler combined with $1.5 \mathrm{~cm}$ seed thickness.

On the other hand, data illustrated that using $0.5 \mathrm{~cm}$ thickness irrigated by $30 \mathrm{sec} / 2 \mathrm{~h}$ recorded the highest sprout yield $(\mathrm{g} / \mathrm{kg}$ seed) followed by the same seed thickness irrigated by $90 \mathrm{sec} / 6 \mathrm{hr}$ while the lowest yield/ tray obtained by mini sprinkler irrigated by $90 \mathrm{sec} / 6 \mathrm{hr}$.

Regarding effect of the interaction among sprinkler type, irrigation period and thickness on sprout yield $(\mathrm{g} / \mathrm{kg}$ seed), data showed that the highest yield was recorded using mini sprinkler combined with $0.5 \mathrm{~cm}$ seed thickness irrigated $30 \mathrm{sec} / 2 \mathrm{hr}$ followed by mist irrigated $90 \mathrm{sec} / 6 \mathrm{hr}$ and fogger combined with the same seed thickness irrigated $30 \mathrm{sec} / 2 \mathrm{hr}$. The lowest yield/tray recorded using all sprinkler combined with $1.5 \mathrm{~cm}$ irrigated $90 \mathrm{sec} / 6 \mathrm{hr}$.

Data in Table (6) presented the effect sprinkler type, period of irrigation and thickness of seeds in the tray on protein percentage in sprout. Data showed that using mist sprayer increased protein percentage in sprout significantly compared with the other type of sprinkler.

Regarding the effect of irrigation period on protein percentage in sprout, data showed that $30 \mathrm{sec} / 2 \mathrm{~h}$ increased protein percentage in sprout significantly comparing with the other irrigation periods.

Data showed also that using $0.5 \mathrm{~cm}$ thickness of seeds in the tray increased protein percentage in sprout significantly comparing with the other seed thickness.

Concerning the effect of interaction between sprinkler type and irrigation period on protein percentage in sprout, data showed that the highest protein percentage in sprout recorded using fogger combined by (30 $\mathrm{sec} / 2 \mathrm{hr}$ ) followed by mist sprinkler with the same irrigation period. The lowest protein percentage in sprout obtained by fogger sprinkler combined with (90 sec/6hr). 
Table (6) Protein (\%) affected by sprinkler type, period of irrigation and thickness of seeds in the tray.

\begin{tabular}{cccccc}
\hline \multirow{2}{*}{ Sprinkler } & Periods & \multicolumn{3}{c}{ Thickness of seeds $(\mathrm{cm})$} & \multirow{2}{*}{ Mean } \\
\cline { 3 - 5 } & $(\mathrm{Sec})$ & 0.5 & 1 & 1.5 & \\
\hline Fogger & $30 \mathrm{sec} / 2 \mathrm{hr}$ & 16.07 & 15.64 & 15.26 & 15.66 \\
& $60 \mathrm{sec} / 4 \mathrm{hr}$ & 14.78 & 13.54 & 0.00 & 9.44 \\
& $90 \mathrm{sec} / 6 \mathrm{hr}$ & 12.83 & 0.00 & 0.00 & 4.28 \\
Mean & & 14.56 & 9.73 & 5.09 & 9.79 \\
Mist sprayer & $30 \mathrm{sec} / 2 \mathrm{hr}$ & 15.03 & 15.14 & 15.76 & 15.31 \\
& $60 \mathrm{sec} / 4 \mathrm{hr}$ & 13.58 & 14.53 & 9.93 & 12.68 \\
& $90 \mathrm{sec} / 6 \mathrm{hr}$ & 14.12 & 12.73 & 0.00 & 8.95 \\
Mean & & 14.24 & 14.13 & 8.56 & 12.31 \\
Mini & & & & & \\
sprinkler & $30 \mathrm{sec} / 2 \mathrm{hr}$ & 14.08 & 14.69 & 0.00 & 9.59 \\
& $60 \mathrm{sec} / 4 \mathrm{hr}$ & 13.14 & 13.32 & 9.76 & 12.07 \\
& $90 \mathrm{sec} / 6 \mathrm{hr}$ & 14.03 & 8.84 & 0.00 & 7.62 \\
Mean & & 13.75 & 12.28 & 3.25 & 9.76 \\
Fogger & & 15.06 & 15.16 & 10.34 & 13.52 \\
Mist sprayer & & 13.83 & 13.80 & 6.56 & 11.40 \\
Mini & & 13.66 & 7.19 & 0.00 & 6.95 \\
sprinkler & & 14.19 & 12.05 & 5.63 & \\
Mean & & & & & \\
\hline
\end{tabular}

LSD value at 0.05 :

Sprinkler (A): 1.54

Periods (B) : 1.54

Thickness (C): 1.54

Interactions: 4.61
$\mathbf{A} \times \mathbf{B}$
$\mathbf{A} \times \mathbf{C}$
$\mathbf{B} \times \mathbf{C}$
$A \times B \times C$

Regarding the interaction between sprinkler type and seed thickness on protein percentage in sprout, data should that using fogger sprinkler combined with $0.5 \mathrm{~cm}$ seed thickness recorded the highest protein percentage in sprout followed by using mist sprinkler with the same seed thickness. The lowest protein percentage in sprout obtained by mini 
sprinkler combined with $1.5 \mathrm{~cm}$ seed thickness. On the other hand, data illustrated that using 1 and $0.5 \mathrm{~cm}$ thickness irrigated by $30 \mathrm{sec} / 2 \mathrm{~h}$ recorded the highest protein percentage in sprout while the lowest protein percentage in sprout obtained by mini sprinkler irrigated by $90 \mathrm{sec} / 6 \mathrm{hr}$.

Regarding effect of the interaction among sprinkler type, irrigation period and thickness on protein percentage in sprout, data showed that the highest protein percentage in sprout was recorded using fogger sprinkler combined with $0.5 \mathrm{~cm}$ seed thickness irrigated $30 \mathrm{sec} / 2 \mathrm{hr}$ followed by mist with the same seed thickness irrigated $30 \mathrm{sec} / 6 \mathrm{hr}$. The lowest protein percentage in sprout recorded using all sprinkler combined with $1.5 \mathrm{~cm}$ irrigated 90sec/6hr.

Table (7) Fiber percentage affected by sprinkler type, period of irrigation and thickness of seeds in the tray.

\begin{tabular}{cccccc}
\hline Sprinkler & Periods & \multicolumn{3}{c}{ Thickness of seeds $\mathbf{( c m )}$} & \multirow{2}{*}{ Mean } \\
\cline { 3 - 5 } & $\mathbf{S e c})$ & $\mathbf{0 . 5}$ & $\mathbf{1}$ & $\mathbf{1 . 5}$ & \\
\hline Fogger & $\mathbf{3 0 s e c / 2 h r}$ & 19.29 & 19.75 & 19.90 & 19.65 \\
& $\mathbf{6 0 s e c / 4 h r}$ & 19.15 & 17.18 & 0.00 & 12.11 \\
& $\mathbf{9 0 s e c / 6 h r}$ & 14.44 & 0.00 & 0.00 & 4.81 \\
Mean & & 17.63 & 12.31 & 6.63 & 12.19 \\
Mist sprayer & $\mathbf{3 0 s e c / 2 h r}$ & 18.05 & 20.05 & 19.24 & 19.11 \\
& $\mathbf{6 0 s e c / 4 h r}$ & 15.91 & 19.25 & 13.09 & 16.08 \\
& $\mathbf{9 0 s e c / 6 h r}$ & 17.29 & 16.73 & 0.00 & 11.34 \\
Mean & & 17.08 & 18.67 & 10.78 & 15.51 \\
Mini & $\mathbf{3 0 s e c / 2 h r}$ & & & & \\
sprinkler & & 19.68 & 20.81 & 0.00 & 13.50 \\
& $\mathbf{6 0 s e c / 4 h r}$ & 15.71 & 15.92 & 11.53 & 14.39 \\
& $\mathbf{9 0 s e c / 6 h r}$ & 18.22 & 11.29 & 0.00 & 9.84 \\
Mean & & 17.87 & 16.01 & 3.84 & 12.57 \\
Fogger & & 19.01 & 20.20 & 13.05 & 17.42 \\
Mist sprayer & & 16.92 & 17.45 & 8.21 & 14.19 \\
Mini & & 16.65 & 9.34 & 0.00 & 8.66 \\
sprinkler & & 17.53 & 15.66 & 7.08 & \\
Mean & & & & & \\
\hline
\end{tabular}

LSD value at 0.05 :

Sprinkler: 1.95

Thickness: 1.95

$\mathbf{A} \times \mathbf{B}$
$\mathbf{B} \times \mathbf{C}$
Periods: 1.95

Interactions: $\mathbf{5 . 8 6}$

$\mathbf{A} \times \mathbf{C}$

$\mathrm{A} \times \mathbf{B} \times \mathbf{C}$ 
Data in Table (7) presented the effect sprinkler type, period of irrigation and thickness of seeds in the tray on fiber percentage in sprout. Data showed that using mist sprayer increased fiber percentage in sprout significantly compared with the other type of sprinkler.

Regarding the effect of irrigation period on fiber percentage in sprout, data showed that $30 \mathrm{sec} / 2 \mathrm{~h}$ increased fiber percentage in sprout significantly comparing with the other irrigation periods.

Data showed also that using $0.5 \mathrm{~cm}$ thickness of seeds in the tray increased fiber percentage in sprout significantly comparing with the other seed thickness.

Concerning the effect of interaction between sprinkler type and irrigation period on fiber percentage in sprout, data showed that the highest fiber percentage in sprout recorded using fogger combined by $(30 \mathrm{sec} / 2 \mathrm{hr}$ ) followed by mist sprinkler with the same irrigation period. The lowest fiber percentage in sprout obtained by fogger sprinkler combined with (90 sec/6hr).

Regarding the interaction between sprinkler type and seed thickness on fiber percentage in sprout, data should that using mist sprinkler combined with $1 \mathrm{~cm}$ seed thickness recorded the highest fiber percentage in sprout followed by using mini sprinkler combined with $0.5 \mathrm{~cm}$ seed thickness. The lowest fiber percentage in sprout obtained by mini sprinkler combined with $1.5 \mathrm{~cm}$ seed thickness.

On the other hand, data illustrated that using 1 and $0.5 \mathrm{~cm}$ thickness irrigated by $30 \mathrm{sec} / 2 \mathrm{~h}$ recorded the highest fiber percentage in sprout while the lowest fiber percentage in sprout obtained by mini sprinkler irrigated by $90 \mathrm{sec} / 6 \mathrm{hr}$.

Regarding effect of the interaction among sprinkler type, irrigation period and thickness on fiber percentage in sprout, data showed that the highest fiber percentage in sprout was recorded using mist and mini sprinklers combined with $1 \mathrm{~cm}$ seed thickness' 8 irrigated $30 \mathrm{sec} / 2 \mathrm{hr}$. The lowest fiber percentage in sprout recorded using all sprinkler combined with 1.5 $\mathrm{cm}$ irrigated $90 \mathrm{sec} / 6 \mathrm{hr}$.

\section{Carbohydrates percentage :}

Data presented in Table (8) presented the effect sprinkler type, period of irrigation and thickness of seeds in the tray on carbohydrate percentage in 
sprout. Data showed that using mist sprayer increased carbohydrate percentage in sprout significantly compared with the other type of sprinkler.

Table (8) Carbohydrates percentage affected by sprinkler type, period of irrigation and thickness of seeds in the tray.

\begin{tabular}{|c|c|c|c|c|c|}
\hline \multirow[t]{2}{*}{ Sprinkler } & \multirow{2}{*}{$\begin{array}{c}\text { Periods } \\
\text { (Sec) }\end{array}$} & \multicolumn{3}{|c|}{ Thickness of seeds $(\mathrm{cm})$} & \multirow{2}{*}{ Mean } \\
\hline & & 0.5 & 1 & 1.5 & \\
\hline \multirow[t]{3}{*}{ Fogger } & 30sec/2hr & 59.51 & 59.25 & 59.32 & 59.36 \\
\hline & $60 \mathrm{sec} / 4 \mathrm{hr}$ & 60.63 & 64.67 & 0.00 & 41.77 \\
\hline & $90 \mathrm{sec} / 6 \mathrm{hr}$ & 61.01 & 0.00 & 0.00 & 20.34 \\
\hline Mean & & 60.38 & 41.31 & 19.77 & 40.49 \\
\hline \multirow[t]{3}{*}{ Mist sprayer } & $30 \mathrm{sec} / 2 \mathrm{hr}$ & 61.05 & 59.73 & 60.31 & 60.36 \\
\hline & $60 \mathrm{sec} / 4 \mathrm{hr}$ & 63.76 & 62.21 & 40.48 & 55.48 \\
\hline & $90 \mathrm{sec} / 6 \mathrm{hr}$ & 61.80 & 63.30 & 0.00 & 41.70 \\
\hline Mean & & 62.20 & 61.75 & 33.60 & 52.51 \\
\hline \multirow[t]{3}{*}{$\begin{array}{c}\text { Mini } \\
\text { sprinkler }\end{array}$} & $30 \mathrm{sec} / 2 \mathrm{hr}$ & 61.01 & 58.78 & 0.00 & 39.93 \\
\hline & $60 \mathrm{sec} / 4 \mathrm{hr}$ & 63.21 & 60.86 & 40.58 & 54.88 \\
\hline & $90 \mathrm{sec} / 6 \mathrm{hr}$ & 59.85 & 44.04 & 0.00 & 34.63 \\
\hline Mean & & 61.35 & 54.56 & 13.53 & 43.15 \\
\hline Fogger & & 60.52 & 59.26 & 39.88 & 53.22 \\
\hline Mist sprayer & & 62.53 & 62.58 & 27.02 & 50.71 \\
\hline $\begin{array}{c}\text { Mini } \\
\text { sprinkler }\end{array}$ & & 60.88 & 35.78 & 0.00 & 32.22 \\
\hline Mean & & 61.31 & 52.54 & 22.30 & \\
\hline
\end{tabular}

LSD value at 0.05 :

Sprinkler: 6.74

Thickness: 6.74

Periods: 6.74

Interactions: $\mathbf{2 0 . 2 2}$

$\mathbf{A} \times \mathbf{C}$

$\mathbf{A} \times \mathbf{B} \times \mathbf{C}$

$\mathbf{B} \times \mathbf{C}$

Regarding the effect of irrigation period on carbohydrate percentage in sprout, data showed that $30 \mathrm{sec} / 2 \mathrm{~h}$ increased carbohydrate percentage in sprout significantly comparing with the other irrigation periods. 
Result showed that using $0.5 \mathrm{~cm}$ thickness of seeds in the tray increased carbohydrate percentage in sprout significantly comparing with the other seed thickness.

Concerning the effect of interaction between sprinkler type and irrigation period on carbohydrate percentage in sprout, data showed that the highest carbohydrate percentage in sprout recorded using mist followed by fogger sprinklers irrigated $30 \mathrm{sec} / 2 \mathrm{hr}$. The lowest carbohydrate percentage in the sprout obtained by fogger sprinkler combined with (90 sec/6hr).

Regarding the interaction between sprinkler type and seed thickness on carbohydrate percentage in sprout, data should that using mist sprinkler combined with $0.5 \mathrm{~cm}$ seed thickness recorded the highest carbohydrate percentage in sprout followed by using the same sprinkler combined with $1 \mathrm{~cm}$ seed thickness. The lowest carbohydrate percentage in sprout obtained by mini sprinkler combined with $1.5 \mathrm{~cm}$ seed thickness.

On the other hand, data illustrated that using 1 and $0.5 \mathrm{~cm}$ thickness irrigated by $30 \mathrm{sec} / 2 \mathrm{~h}$ recorded the highest carbohydrate percentage in sprout while the lowest carbohydrate percentage in sprout obtained by mini sprinkler irrigated by $90 \mathrm{sec} / 6 \mathrm{hr}$.

Regarding effect of the interaction among sprinkler type, irrigation period and thickness on carbohydrate percentage in sprout, data showed that the highest carbohydrate percentage in sprout was recorded using fogger combined with $1 \mathrm{~cm}$ seed thickness followed by mist sprinklers combined with $0.5 \mathrm{~cm}$ seed thickness irrigated $60 \mathrm{sec} / 2 \mathrm{hr}$. The lowest carbohydrate percentage in sprout recorded using all sprinkler combined with $1.5 \mathrm{~cm}$ irrigated $90 \mathrm{sec} / 6 \mathrm{hr}$.

\section{CONCLUSION}

From the overall results, it is clear that using $0.5 \mathrm{~cm}$ seed thickness irrigated by fogger every $30 \mathrm{sec} / 2 \mathrm{hr}$ the best combination to get the highest yield and other parameter of sprouts.

\section{REFERENCES}

Al-Hashmi, M. M. 2008. Hydroponic green fodder production in the Arabian Gulf Region. MSc . Thesis, Faculty of Graduate Studies, Arabian Gulf University, Bahrain. 
Al-kraki,G.N. and M. Al-Hashimi. 2012 . Green Fodder Production and Water Use Efficiency of Some Forage Crops under Hydroponic Conditions . ISRN Agronomy. V (2012) 5PP.

Al-kraki,G.N. and N. Al-Momani. 2011. Evaluation of Some Barley Cultivars for Green Fodder Production and Water Use Efficiency under Hydroponic Conditions . Jordan Journal of Agricultural Sciences, 7(3) : 448-456.

Al-Karaki, G. N. 2010. Hydroponic green fodder:alternative method for saving water in dry areas.In Proceedings of the "Second Agricultural Meeting on Sustainable Improvement of Agricultural and Animal Production and Saving Water Use. September 2010, Sultanate of Oman.

Bradley, P. and C, Marulanda. 2000 "Simplified hydroponics to reduce global hunger," Acta Horticulture. (554) : 289-295 .

Dung, D.D . I.R.Godwin , J.V. Nolan. 2010. Nutrient content and in sacco Digestibility of Barley Grain and sprouted Barley. Animal and veterinary Advances journal 9(19) : 2485- 2492.

El-Deeba , M . M. 2009 . Production of fresh grass forage by hydroponic system .MSc. Thesis, Dep. of Agric. Mech. Fac. of Ag., Ain Shams University.

Gharineh MH, Bakhshandeh A, Ghasemi-Golezani K. 200 4. Vigor and seed germination of wheat cultivar in Khuzestan environmental condition. Sci J of Agr 27:65-76.

Howard, M.1989. Hydroponic Food Production. Santa Barbara. California $93160: 26$

Keller, J. and Blienser, R.D. 1990. Sprinkler and Trickle Irrigation. AVI Book. Van Norstrand Reinhold, New York.

Montero, J., J. M.Tarjuelo, and J. F. Ortega .1999. Heterogenity analysis of the irrigation in fields with medium size sprinkler. Universidad de Castilla-La Mancha. Campus Universitario s/n, Albacete Spain .

Moshatati, A. Gharineh, M.H.,2012. Effect of grain weight on germination and seed vigor of wheat. Intl.J.Agri.crop sci. Vol.,4(8), $458-460,2012$ 
Mosh, S., 2006. Guidelines for planning and design of micro irrigation in arid and semiarid regions. Int. Comm. Irri. And Drai. (ICID).

Rodriguez-Mulea, C., H. E.Rodriguez, O.Ruiz, A.Flores, J. A. Grado and C. Arzola. 2004. Use of Green Fodder Produced in Hydroponic System as Supplement for Lactating Cows During the Dry Season. Proceeding of American Society of Animal Science, 56: 271-274. (Western Section)

Sandra P., P. Paul, G.Fernando and K.Jack. 2001. Drip irrigation for small farmers. Water international, 26:1, 3-13 .

Schorder , F. Lieth, J . 2002 . Irrigation control in hydroponics . D. Savvas and H.Passam (Eds), Hydroponi production of vegetables and ornamentals, Chapter 7 .pp. 263- 298 .

Silva, F. de A. S. e. \& Azevedo, C. A. V. de. 2009. Principal Components Analysis in the Software Assistat-Statistical Attendance. In:WORLD CONGRESS ON COMPUTERS IN AGRICULTURE, 7, Reno-NV-USA: American Society of Agricultural and Biological Engineers p.393-396.

Snedecor G. A. and Cochran W. G. (1994). Statistical Method. Iowa State Univ. Press, Ames .

$$
\text { الملخص العربي }
$$

تأثير نظم الرى الصغيرة وفترة الرى وسمك طبقة البذور

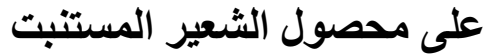

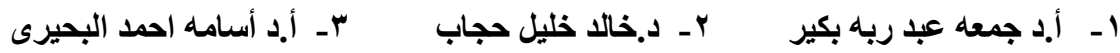

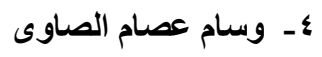

كان الهذف الرئيسي من هذا البحث دراسة تأثير نظم الرى المختلفة في الزر اعة المائية لإنتاج

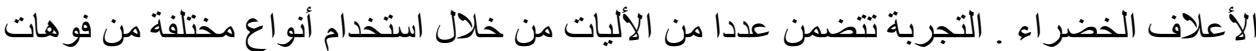

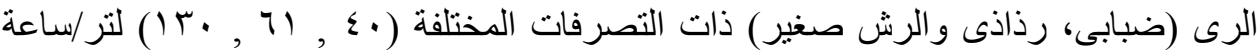

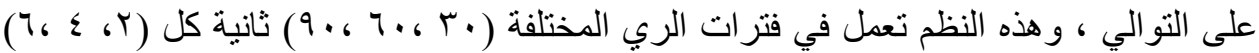

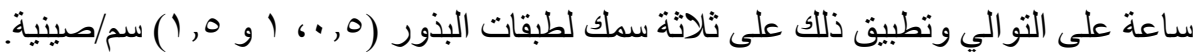

1- أستاذ الهندسة الزراعية ـ كلية الزراعة جامعة القاهرة

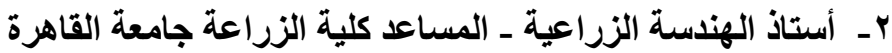

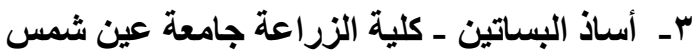
ع- طالبة دراسات عليا بقسم الهندسة الزراعية ــ كلية الزراعة - جامعة القاهرة 


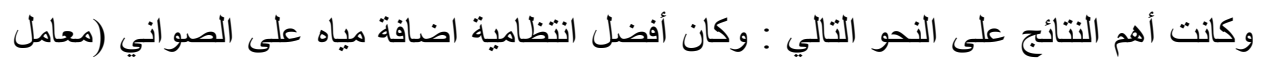

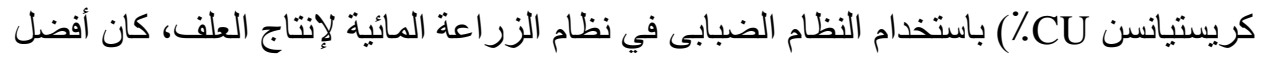

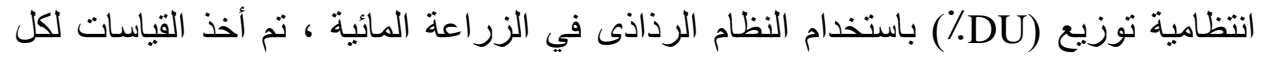

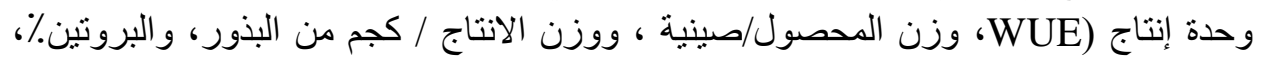
و الألياف\%، و الكربو هيدر اتش\%).

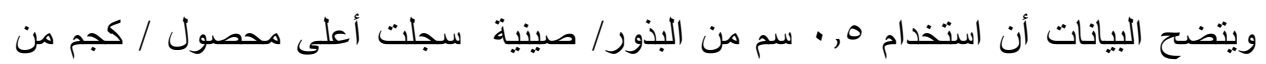

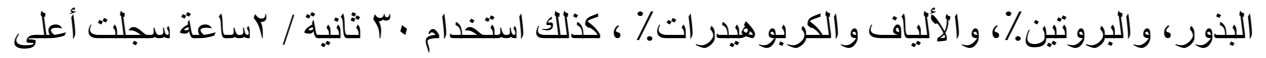

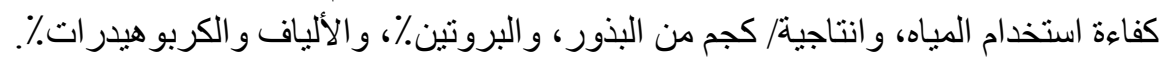

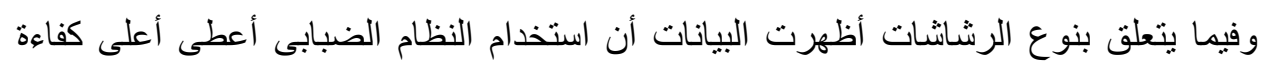

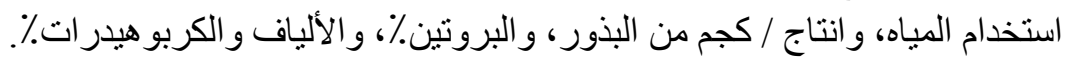

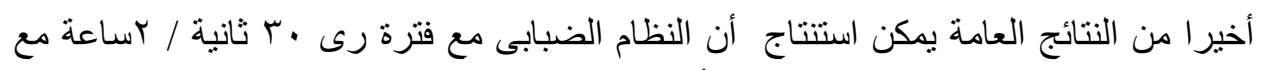
0, • سم سمك البذور داخل الصينية سجلت أعلى المعايير التي تم اختبار ها. 